Abstract S157 Table 1 Summary of results using a priori risk estimates

\begin{tabular}{|c|c|c|c|c|c|}
\hline $\begin{array}{l}\text { Exposure } \\
\text { definition }\end{array}$ & $\begin{array}{l}\text { No of cases } \\
\text { in high-risk } \\
\text { job }\end{array}$ & $\begin{array}{l}\text { No of controls } \\
\text { in high-risk } \\
\text { job }\end{array}$ & $\begin{array}{l}\text { Odds Ratio } \\
\text { adjusted }\end{array}$ & $\begin{array}{l}95 \% \\
\text { Confidence } \\
\text { Interval }\end{array}$ & p value \\
\hline \multicolumn{6}{|l|}{ JEM } \\
\hline All & 81 & 172 & 0.76 & $0.55-1.04$ & 0.08 \\
\hline Adult onset & 59 & 145 & 0.82 & $0.57-1.18$ & 0.29 \\
\hline Childhood worsening & 22 & 27 & 0.62 & $0.31-1.22$ & 0.17 \\
\hline \multicolumn{6}{|l|}{ ECRHS } \\
\hline All & 109 & 215 & 0.90 & $0.68-1.19$ & 0.46 \\
\hline Adult onset & 80 & 181 & 0.98 & $0.71-1.35$ & 0.90 \\
\hline Childhood worsening & 29 & 34 & 0.70 & $0.38-1.29$ & 0.25 \\
\hline \multicolumn{6}{|l|}{ SWORD } \\
\hline All & 9 & 31 & 0.49 & $0.23-1.04$ & 0.06 \\
\hline Adult onset & 6 & 28 & 0.44 & $0.18-1.08$ & 0.07 \\
\hline Childhood worsening & 3 & 3 & 0.85 & $0.16-4.41$ & 0.84 \\
\hline
\end{tabular}

\section{S158 OCCUPATIONAL ASTHMA; REFERRAL PATTERNS FROM PRIMARY CARE IN THE UK}

doi:10.1136/thx.2010.150953.9

${ }^{1} \mathrm{~J}$ L Hoyle, ${ }^{2} \mathrm{~L}$ Hussey, ${ }^{2} \mathrm{R}$ Agius. ${ }^{1}$ North Manchester General Hospital, Manchester, England, UK; ${ }^{2}$ Centre for Occupational \& Environmental Health, The University of Manchester, Manchester, England, UK

Introduction and Objectives Occupational asthma is the commonest reported occupational lung disease in the $\mathrm{UK}^{1}$.The British Occupational Health Research Foundation (BOHRF) ${ }^{2}$ guidelines 2010 recommend that 'all family practices be able to screen for occupational asthma, and have a plan for further management'. The standards of care for occupational asthma ${ }^{3}$ recommend 'early referrals to a specialist with an interest in occupational asthma if such a diagnosis is suspected'. This referral should take place 'after occupational asthma is screened for before important life decisions are made'. (SIGN guidelines ${ }^{4}$ ). Very little is known about the proportion of cases that are referred on to clinical specialists once identified.

Methods The Health \& Occupation Reporting network in General Practice (THOR-GP) at the University of Manchester, collects workrelated ill-health data between 250 and 300 GPs trained to diploma level in occupational medicine. Cases with a diagnosis of occupational asthma reported in 2006-2009 were divided into subgroups by their causative agent. Cases referred to a hospital specialist were compared to those not referred.

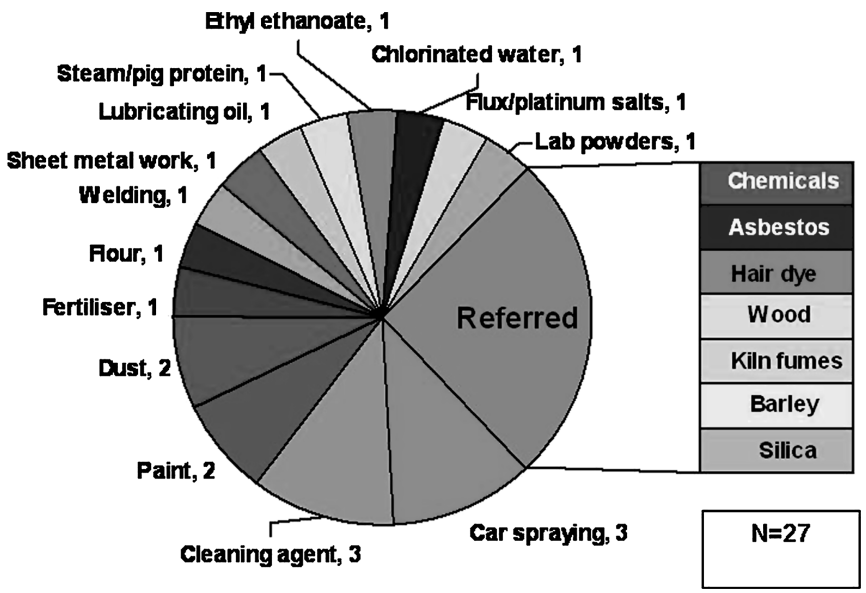

Abstract S158 Figure 1 Agents attributed to asthma cases referred to hospital specialists THOR-GP 2006-2009.
Results In 2006-2009, GPs reported 4902 cases of work-related illhealth, of which $115(2 \%)$ were reports of respiratory disease. 33 were diagnosed with asthma, 6 were referred to a hospital specialist (Abstract S158 Figure 1). The cases not referred included workers exposed to a variety of known asthmagens.

Conclusion Despite national recommendations, these data show that the majority of cases suspected as having occupational asthma are not referred to hospital specialists from primary care. It is not known if the lack of referral affects outcome with regards to disease prognosis, disability or employment status.

\section{S159 DO OCCUPATIONAL ASTHMATICS WITH SMALL CHANGES IN PEF AT WORK HAVE LESS FEV1 DECLINE THAN THOSE WITH LARGER CHANGES?}

doi:10.1136/thx.2010.150953.10

W Anees, V C Moore, P S Burge. Birmingham Heartlands Hospital, Birmingham, UK

Background The significance of consistent small changes in PEF related to work, or records with diurnal variation within the normal range, are disputed. We related PEF changes at diagnosis to longitudinal changes in FEV1 in workers remaining exposed to their causative agent.

Methods 163 consecutive workers attending a tertiary referral clinic were identified. All had a clinical history suggestive of occupational asthma and a diagnostic serial PEF record (Oasys score $>2.50$ ). Average annual rate of $\mathrm{FEV}_{1}$ decline was calculated using simple linear regression for each worker with at least 12 months of FEV1 measurements. PEF responses to work exposure were made from the initial diagnostic PEF record. Subjects were split into tertiles according to their PEF responses. Mean work-rest PEF was $>35 \mathrm{l} / \mathrm{min}$ in the highest tertile and $<20 \mathrm{l} / \mathrm{min}$ in the lowest. Corresponding values for diurnal variation (DV) $\%$ predicted were $\geq 16 \%$ (high) and $<10 \%$ (low) Results Ninety workers had FEV1 measurements for at least 12 months during exposure to the original causative agent (median 2.9 years, IOR $1.8-4.8$ years). The mean annual loss of FEV1 was increased at 101 (SEM 17.7) $\mathrm{ml} /$ year, unrelated to agent; high MW (10), isocyanates (16), metals (13), colophony (9), biocides (10), metal working fluid (7) and others (23). There were no significant differences related to continued smoking or treatment. There were large between individual differences with annual declines $<50 \mathrm{ml}$ in $35 / 90$ workers. There were no statistically significant differences between those with high rest-work PEF changes (-126 SEM $44 \mathrm{ml} /$ year), and low changes (95 SEM $22.1 \mathrm{ml} /$ year), or between those with high DV (98 SEM $36.5 \mathrm{ml} /$ year) and low DV (142 SEM $30.3 \mathrm{ml} /$ year).

Conclusion Some workers with occupational asthma have normal FEV1 decline during continued exposure, but the average is around $3 \times$ predicted. Workers with small work-related PEF changes or low DV do as badly as those with larger values. The classification of FEV1 decline in an individual worker requires longer measurements than we have available; the group mean changes should be more reliable. Those who are able to remain exposed are likely to be those with least severe disease.

\section{S160 THE EFFECT OF SHIFT WORK ON SERIAL PEAK EXPIRATORY FLOW MEASUREMENTS USED TO DIAGNOSE OCCUPATIONAL ASTHMA}

doi:10.1136/thx.2010.150953.11

${ }^{1} \mathrm{~V}$ C Moore, ${ }^{2} \mathrm{M}$ S Jaakkola, ${ }^{1} \mathrm{C}$ B S G Burge, ${ }^{3} \mathrm{C}$ F A Pantin, ${ }^{1}$ A S Robertson, ${ }^{1} \mathrm{P}$ S Burge. ${ }^{1}$ Birmingham Heartlands Hospital, Birmingham, UK; ${ }^{2}$ Oulu University, Oulu, Finland; ${ }^{3}$ University Hospital of North Staffordshire, Stoke on Trent, UK

We investigated the effects of shift work on Peak Expiratory Flow (PEF) measurements used for diagnosing occupational asthma (OA). 